\title{
HENRY I
}

\section{Warren Hollister}

Edited and completed by Amanda Clark Frost 
Copyright ( 2001 by The Estate of C. Warren Hollister Foreword @ 2001 by Jeffrey Burton Russell

Preface (C) 2001 by Amanda Clark Frost First published in paperback 2003

All rights reserved. This book may not be reproduced in whole or in part, in any form (beyond that copying permitted by Sections 107 and 108 of the U.S. Copyright Law and except by reviewers for the public press) without written permission from the publishers.

For information about this and other Yale University Press publications, please contact:

U.S. Office: sales.press@yale.edu www.yalebooks.com Europe Office: sales@yaleup.co.uk www.yalebooks.co.uk

Set in New Baskerville by Best-set Typesetter Ltd, Hong Kong

Printed in Great Britain by Hobbs the Printers Ltd, Totton, Hampshire

A catalogue record for this book is available from the Library of Congress and the British Library

ISBN 978-0-300-08858-8 (lbk.)

ISBN 978-0-300-09829-7 (pbk.) 
HENRY I 
Also in the Yale English Monarchs Series

ATHELSTAN by Sarah Foot

EDWARD THE CONFESSOR by Frank Barlow

WILLIAM THE CONQUEROR by David Douglas*

WILLIAM RUFUS by Frank Barlow

HENRY I by Warren Hollister

KING STEPHEN by Edmund King

HENRY II by W. L. Warren*

RICHARD I by John Gillingham

KING JOHN by W. L. Warren*

EDWARD I by Michael Prestwich

EDWARD II by Seymour Phillips

RICHARD II by Nigel Saul

HENRY V by Christopher Allmand

HENRY VI by Bertram Wolffe

EDWARD IV by Charles Ross

RICHARD III by Charles Ross

HENRY VII by S. B. Chrimes

HENRY VIII by J. J. Scarisbrick

EDWARD VI by Jennifer Loach

MARY I by John Edwards

JAMES II by John Miller

QUEEN ANNE by Edward Gregg

GEORGE I by Ragnhild Hatton

GEORGE II by Andrew C. Thompson

GEORGE III by Jeremy Black

GEORGE IV by E. A. Smith

* Available in the U.S. from University of California Press 
For Edith 
